\title{
Misi Gereja dalam Mewujudkan Keadilan Sosial: Sebuah Perspektif dari Sila Kelima Pancasila
}

\author{
Piter Randan Bua ${ }^{1}$, David Samiyono ${ }^{2}$, Tony Christian Tampake ${ }^{3}$ \\ ${ }^{1,2,3}$ Fakultas Teologia, Universitas Kristen Satya Wacana, Salatiga \\ 1752017019@student.uksw.edu, ${ }^{2} d \_s a m i y o n o @ y a h o o . c o m,{ }^{3}$ tony.robert@staff.uksw.edu
}

\begin{abstract}
This article aims to see the mission of the Gereja Kristen Indonesia (GKI Peterongan) in the perspective of the fifth principle of Pancasila namely social justice for all Indonesian people. Social justice in the perspective of the fifth principle of Pancasila is political justice and economic justice. Equally the same is based on the constitution and the same sense in the economic field. The meaning of social justice is built on the basis of kinship and mutual cooperation and all for all. The method used in this study uses qualitative methods through the study of documents, interviews and observations. In this study it was found that GKI Peterongan aspires to realize social justice for all people but has not been reflected and implemented in existing programs. In reality the implementation of the GKI Peterongan mission has not yet led to the realization of social justice for all Indonesian people. The mission of the GKI Peterongan is still exclusive and qualitative and has not given much thought to the community outside the church.
\end{abstract}

\begin{abstract}
Abstrak
Artikel ini bertujuan melihat misi Gereja Kristen Indonesia Peterongan (GKI Peterongan) dalam perspektif Sila Kelima Pancasila yaitu Keadilan Sosial bagi seluruh rakyat Indonesia. Keadilan Sosial dalam perspektif Sila Kelima Pancasila adalah keadilan politik dan keadilan ekonomi. Sama - sama rata sama rasa berdasarkan konstitusi dan sama rata - sama rasa dalam lapangan ekonomi. Artinya keadilan sosial yang dibangun atas dasar kekeluargaan dan gotong royong serta semua untuk semua. Metode yang digunakan dalam penelitian ini menggunakan metode kualitatif melalui studi dokumen, wawancara dan observasi. Pada penelitian ini ditemukan bahwa GKI Peterongan bercita - cita mewujudkan keadilan sosial bagi seluruh rakyat namun belum tercermin dan terimplementasi dalam program - program. Kenyataannya pelaksanaan misi GKI Peterongan belum mengarah pada perwujudan keadilan sosial bagi seluruh rakyat Indonesia. Misi GKI Peterongan masih bersifat ekslusif dan karitatif serta belum banyak memikirkan masyarakat di luar gereja.
\end{abstract}

Article History

Submit:

07 April 2019

Revised:

05 Oktober 2019

Accepted:

13 Oktober 2019

Keywords

(kata kunci):

church

mission;

GKI

peterongan; social

justice;

keadilan sosial;

misi gereja; 


\section{Pendahuluan}

Masyarakat adil dan makmur adalah tujuan akhir dari revolusi Indonesia. Soekarno dalam pidatonya di Gedung Negara Yogyakarta 20 Februari 1959 mengatakan, 'Masyarakat adil dan makmur, cita - cita asli dan murni dari rakyat Indonesia yang telah berjuang dan berkorban berpuluh - puluh tahun. Masyarakat adil dan makmur tujuan akhir dari revolusi kita. Masyarakat adil dan makmur yang untuk itu, berpuluh - puluh ribu pemimpin - pemimpin kita menderita. Perpuluh - puluh ribu pemimpin - pemimpin kita meringkuk dalam penjara. Perpuluh - puluh ribu pemimpin - pemimpin kita meninggalkan kebahagiaan hidupnya. Beratus - ratus ribu, mungkin jutaan rakyat kita menderita tak lain tak bukan ialah mengejar cita - cita terselenggaranya satu masyarakat adil dan makmur yang di situ segenap manusia Indonesia dari Sabang sampai Merauke mengecap kebahagiaan'. Cita - cita tentang masyarakat adil dan makmur ini telah lama bergejolak dalam sanubari masyarakat Indonesia bahkan sejak zaman prasejarah. ${ }^{1}$

Pada masa perjuangan kemerdekaan visi tentang keadilan dan kesejahteraan rakyat diidealisasikan oleh para pejuang pergerakan dan mewarnai diskusi tentang dasar falsafah negara dalam persidangan BPUPKI. Klimaksnya ketika Soekarno mengungkapkannya dalam pidatonya pada 1 Juni 1945 yang kemudian dijadikan sebagai hari lahirnya Pancasila. Soekarno dalam pidatonya mengatakan, 'Prinsip nomor empat sekarang saya usulkan... yaitu prinsip kesejahteraan; tidak ada kemiskinan di dalam Indonesia merdeka'2 ${ }^{2}$ Ide dan mimpi tentang kesejahteraan sosial ini kemudian dirumuskan sebagai salah satu unsur yang menyusun dasar falsafah Bangsa Indonesia sebagaimana tercantum dalam Pancasila Sila Kelima yang berbunyi, 'Keadilan sosial bagi seluruh rakyat Indonesia' seterusnya mewarnai konstitusi Negara Indonesia.

Meski visi tentang keadilan sosial telah lama bergelora dan diperjuangkan oleh Bangsa Indonesia bahkan telah termuat dengan rinci dalam konstitusi negara namun belum terwujud dengan baik. Kenyataannya, kesejahteraan sosial belum terwujud untuk semua dan kesenjangan ekonomi masih terjadi dalam masyarakat kita. Berdasarkan data Badan Pusat Statistik Indonesia pada Bulan September 2017 menunjukkan bahwa jumlah rakyat Indonesia yang masih hidup di bawah garis kemiskinan mencapai 26,58 juta orang (10,12 persen $)^{3}$. Sementara itu di Jawa Tengah persentase penduduk miskin per September 2017 sebesar 12, 23 persen. $^{4}$

Melihat hal ini gereja - gereja di Indonesia sebagai komponen yang tak terpisahkan dari Negara harus menyadari bahwa kesejahteraan Indonesia juga adalah kesejateraan gereja. Seperti ungkapan Yeremia 29:7, 'Usahakanlah kesejahteraan kota ke mana kamu Aku buang, dan berdoalah untuk kota itu kepada TUHAN, sebab kesejahteraannya adalah kesejahteraanmu'. Berdasarkan hal ini gereja seharusnya peduli dan ikut berpartisipasi

\footnotetext{
1 Yudi Latief. Negara Paripurna (Jakarta: PT. Gramedia Pustaka Utama, 2011), 494

2 (Latif, 2011: 495)

${ }^{3}$ https://www.bps.go.id. Data ini dirilis Badan Pusat Statistik RI tanggal 2 Januari 2018

${ }^{4}$ https/jateng.bps,id/pressrilis2januri2018.
} 
mewujudkan cita - cita bangsa Indonesia. Cita - cita itu adalah keadilan sosial bagi seluruh rakyat Indonesia seperti termaktub dalam Sila Kelima Pancasila dan UUD 1945.

Beberapa tahun terakhir para penulis terdahulu telah meneliti tentang misi gereja - gereja di Indonesia antara lain: Rekontruksi Misi Gereja di Indonesia ${ }^{5}$, Misi Gereja di Tengah Pluralitas Agama dan Budaya ${ }^{6}$,Misi Gereja di Indonesia dan Pengaruhnya Terhadap Umat Islam ${ }^{7}$, Konsep Misi Diakonia untuk Konteks Indonesia ${ }^{8}$,Gereja dan Kemiskinan: Diskursun Peran Gereja di Tengah Kemiskinan", Mengimplementasikan Pelayanan Yesus dalam Konteks Misi Masa Kini Menurut Injil Sinoptik ${ }^{10}$, Dimensi Politik dari Misi Pembebasan Gereja Bagi Orang Miskin dan Pemeliharaan Alam Ciptaan ${ }^{11}$ dan Rekontruksi Misi di Abad $21^{12}$. Setelah menelaah penelitian - penelitian tersebut penulis tidak menemukan kajian yang secara khusus membahas tentang misi gereja dari perspektif sila kelima Pancasila. Karena itu tulisan ini secara khusus akan membahas misi gereja dari perspektif keadilan sosial berdasarkan sila kelima Pancasila. Menurut Ir Soekarno keadilan sosial berdasarkan sila kelima Pancasila adalah keadilan ekonomi dan keadilan politik. ${ }^{13}$

Tulisan ini didasarkan pada misi Gereja Kristen Indonesia (GKI) Peterongan Semarang yang berdiri 31 Oktober 1966 dan telah menjelma menjadi gereja yang besar dan cukup berpengaruh di lingkungan GKI secara khusus dan masyarakat pada umumnya. Tulisan ini berjudul, 'Gereja dan Keadilan Sosial: Misi Gereja Kristen Indonesia (GKI) Peterongan Semarang dari Perspektif Sila Kelima Pancasila'. Pertanyaan utama yang akan dijawab dalam tulisan ini adalah, 'Bagaimana pelaksanaan misi GKI Peterongan Semarang dalam perspektif Sila Kelima Pancasila?'

Penelitian ini menggunakan pendekatan kualitatif, yang menurut John W Creswell sebagai metode penelitian yang sudah memiliki pendekatan dan prosedur - prosedur yang lengkap dan jelas, sehingga bisa membuat deskripsi yang komprehensif ${ }^{14}$. Clifford Geertz menyebutnya thick description yakni sebuah deskripsi tentang makna, filosofi dan cara berpikir dari komunitas yang menjadi obyek penelitian. Sehingga apa yang dibuat peneliti bukan berdasarkan apriori namun berdasarkan pada interpretasinya dalam melakukan

\footnotetext{
${ }^{5}$ I Made Priana. Misi Gereja Kristen di Bali dalam Perspektif Pancasila (Salatiga: Fakultas Teologia Universitas Kristena Satya Wacana, 2017), 164

${ }^{6}$ Y Haryprabowo. Misi Gereja Di Tengah Pluralitas Agama Dan Budaya. Orientasi Baru. Vol.18 (2009), $33-49$.

${ }^{7}$ Tarpin. Misi Kristen Di Indonesia Bahaya Dan Pengaruhnya Terhadap Umat Islam. Ushuluddin. Vol.17 (2011), 38-53

${ }^{8}$ Sudianto Manullang. Konsep Misi Diakonia Untuk Konteks Indonesia. Stulos. Vol.16 (2018), 28-46

${ }^{9}$ Fibry Jati Nugroho. Gereja Dan Kemiskinan: Diskursus Peran Gereja Di Tengah Kemiskinan. Evangelikal. Vol. 3 (2019), 100-112

${ }^{10}$ Kalis Stevanus. Mengimplementasikan Pelayanan Yesus Dalam Konteks Misi Masa Kini Menurut Injil Sinoptik. Fidei. Vol. 1 (2018), 284-95

${ }^{11}$ Alexander Jebadu. Dimensi Politik Dari Misi Pembebasan Gereja Bagi Orang Miskin Dan Pemeliharaan Alam Ciptaan. Teologi. Vol. 6 (2017), 167-186

${ }^{12}$ Fredy Siagian. Rekontruksi Misi Gereja Di Abad 21. Sintax Literate. Vol. 1 (2016), 1-13

13 (Latif, 2011:498)

${ }^{14}$ John W Creswell. Reseach Desaign (Yogyakarta: Pustaka Pelajar, 2010), 19.
} 
observasi, eksplorasi dan investigasi, bahasa tubuh, bahasa lisan, bahasa tertulis, perilaku dan simbol - simbol dari komunitas yang diteliti. ${ }^{15}$

Teknik pengumpulan data yang digunakan yakni, pertama, wawancara terhadap pendeta dan majelis jemaat. Kedua, studi dokumen terhadap dokumen - dokumen yang dimiliki oleh GKI Peterongan. Ketiga, observasi dengan terlibat secara langsung melihat pelaksanaan program - program GKI Peterongan.

\section{Keadilan Sosial dalam Perspektif Sila Kelima Pancasila}

Bangsa Indonesia dalam masa pendudukan Belanda dan Jepang mengalami penindasan dan ketidakadilan. Berbagai bentuk ketidakadilan yang dialami Bangsa Indonesia pada masa itu antara lain: 1). Kebebasan dan sumber - sumber penghidupannya dirampas untuk kepentingan penjajah sehingga kehilangan kebebasan dan sumber - sumber penghidupannya. 2). Indonesia mengalami diskriminasi dalam berbagai bidang kehidupan dan direndahkan, sekadar menjadi alat pemuas kebutuhan penjajah. Harga dirinya ditindas, akibatnya kehilangan rasa percaya diri untuk melawan penjajah. ${ }^{16}$

Perlakuan inilah yang mendorong bangsa Indonesia memperjuangkan kemerdekaannya untuk lepas dari cengkraman para penjajah. Indonesia bertekad bahwa segala bentuk ketidakadilan yang dialami selama penjajahan tidak boleh lagi ada dalam Indonesia merdeka. Ir. Soekarno di depan BPUPKI (Badan Penyelidikan Usaha Persiapan Kemerdekaan Indonesia) 1 Juni 1945 berkata, 'Prinsip nomor empat sekarang saya usulkan. Saya di dalam tiga hari ini belum mendengarkan prinsip itu yaitu prinsip kesejahteraan, prinsip tidak akan ada kemiskinan di dalam Indonesia merdeka. ${ }^{17}$

Hal ini diungkapkan Soekarno karena ia ingin Indonesia yang merdeka kelak rakyatnya sejahtera, cukup makan, cukup pakaian, hidup dalam kesejahteraan, merasa dipangku oleh ibu pertiwi yang cukup memberi sandang dan pangan kepadanya. Karena itu menurut Soekarno Indonesia merdeka tidak boleh seperti negara - negara Eropa dan Amerika yang hanya menganut parlementaire democratic dengan sistem kapitalis. Indonesia merdeka harus menganut sistem demokrasi yang berkeadilan sosial (sociale rechtvaardigheid) dan demokrasi ekonomi (economiche democratic). Soekarno berucap, 'Saudara - saudara, saya usulkan kalau kita mencari demokrasi, hendaknya bukan demokrasi Barat, tetapi permusyawaratan yang memberi hidup, yakni politeik economische democratic yang mampu mendatangkan kesejahteraan sosial'. ${ }^{18}$

Ia pun mengatakan bahwa kesejahteraan sosial telah lama dibicarakan rakyat Indonesia:

'Rakyat Indonesia sudah lama bicara tentang hal ini' Apakah yang dimaksud dengan Ratu Adil? Yang dimaksud dengan paham Ratu Adil ialah socialerechtvaardigheid, rakyat ingin sejahtera. Rakyat yang tadinya merasa dirinya kurang makan, kurang pakaian;

\footnotetext{
15 (Priana, 2017:11-12)

${ }^{16}$ Pamoe Raharjo. Bung Karno dan Pancasila (Yogyakarta:Galang Press, 2002), 29

${ }^{17}$ Floriberta Aning (Penyunting). Lahirnya Pancasila: Kumpulan Pidato BPUPKI (Jakarta:Penerbit Media Pressindo, 2006), 144

18 (Aning, 2016:147)
} 
menciptakan dunia yang baru yang di dalamnya ada keadilan, di bawah pimpinan Ratu Adil. Oleh karena itu jikalau kita memang betul - betul mengerti, mengingat rakyat Indonesia marilah kita terima prinsip hal sociale rechtvaardigheid ini, yaitu bukan saja persamaan politeik, saudara - saudara, tetapi pun di atas lapangan ekonomi kita itu harus mengadakan persamaan, artinya kesejahteraan bersama yang sebaik - baiknya. Saudara - saudara, badan permusyawaratan yang kita akan buat hendaknya bukan badan permusyawaratan politeik demokratie tetapi badan yang bersama dengan masyarakat dapat mewujudkan dua prinsip: politieke rechtvaardigheid dan sociale rechtvaardigheid'. 19

Soekarno selanjutnya dalam Kursus Pancasila di Istana Negera 5 Juli 1958 dan Amanat Presiden Soekarno pada Penutupan Seminar Pancasila di Gedung Negara Yogyakarta 20 Februari 1959 mengungkapkan bahwa keadilan sosial itu mencakup keadilan politik dan keadilan ekonomi. Sama rata sama rasa dalam lapangan politik dan lapangan ekonomi. Bahkan Soekarno dengan tegas mengatakan bahwa negara adalah alat untuk mewujudkan cita - cita masyarakat adil dan makmur ${ }^{20}$.

Senada dengan Soekarno, Moh. Hatta juga mengungkapkan bahwa strategi yang efektif untuk merawat dan memperkuat bangsa melawan komunisme dengan menghargai manusia dari segi lahirnya dan memperbaiki taraf kehidupan rakyat secara fisik. Hatta juga berkata bahwa, 'Demokrasi politik saja tidak akan mewujudkan persamaan dan persaudaraan Indonesia. Di samping demokrasi politik, Indonesia melalui sila kelima Pancasila, juga memberlakukan demokrasi sosial ekonomi. Tanpa demokrasi politik dan ekonomi, Indonesia belum merdeka, Indonesia belum hidup dalam persamaan dan persaudaraan' ${ }^{21}$

Keadilan politik itu berarti sama - sama mempunyai hak dipilih, memiliki hak yang sama mengeluarkan pendapat, menjadi menteri, menjadi hakim dan menjadi apapun. Keadilan politik itu sama rata - sama rasa menurut Undang -Undang Dasar ${ }^{22}$. Sedangkan keadilan ekonomi itu berarti sama rata - sama rasa dalam lapangan ekonomi. Artinya setiap warga negara berhak untuk memperoleh hak - hak ekonominya, pengetahuan dan keahlian untuk bekerja memperoleh penghasilan. Setiap warga negara memiliki hak yang sama untuk memanfaatkan fasilitas - fasilitas yang disediakan pemerintah untuk meningkatkan ekonominya. Demikian pula setiap warga negara memiliki hak yang sama untuk menduduki jabatan - jabatan dan pekerjaan sebagai sumber penghasilan. Keadilan ekonomi berarti setiap warga negara bukan hanya tidak boleh menderita karena kemiskinan tetapi juga tidak boleh memperoleh dan menikmati kekayaan karena memeras sesamanya baik secara halus maupun $\operatorname{kasar}^{23}$.

Dalam Rapat Besar Panitia Perancang Undang - Undang Dasar 13 Juli 1945 yang diketuai oleh Soepomo persoalan keadilan dan kesejahteraan sosial diakomodasi dalam bab

\footnotetext{
19 (Aning, 2016:147)

${ }^{20}$ Ir. Soekano. Revolusi Indonesia: Nasionalisme, Marhaen dan Pancasila (Yogyakarta: Galangpress, 2002), 135-161 dan 217-232.

${ }^{21}$ (Priana, 2017:94-95)

22 (Soekarno, 2002:145)

23 Thobias A Messakh. Konsep Keadilan dalam Pancasila (Salatiga: Satya Wacana University Press, 2007), 172
} 
tentang warga negara, Pasal 27 ayat 2 dan bab tentang kesejahteraan sosial, pasal 31 dan 32 . Pasal 27 ayat 2 berbunyi, 'Tiap - tiap warga Negara berhak atas pekerjaan dan penghidupan yang layak bagi kemanusiaan. Pasal 31 berbunyi, 'Perekonomian disusun sebagai usaha bersama berdasarkan atas asas kekeluargaan (ayat 1)', 'Cabang - cabang produksi yang penting bagi Negara dan yang menguasai hajat hidup orang banyak dikuasai oleh Negara (ayat 2)', 'Bumi dan air dan kekayaan alam yang terkandung di dalamnya dikuasai oleh negara dan harus dipergunakan untuk sebesar - besarnya untuk kemakmuran rakyat (ay at 3)'. Pasal 32 berbunyi, 'Fakir miskin dan anak - anak terlantar dipelihara oleh Negara' ${ }^{24}$.

Jelas sekali bahwa keadilan sosial dalam konteks Sila Kelima Pancasila adalah kesejahteraan sosial dan pemerataan ekonomi dalam semangat kegotong royongan. Di mana semua masyarakat Indonesia hidup sejahtera karena berdaya secara ekonomi serta sumber sumber penghidupan secara ekonomi tidak dikuasai oleh segelintir orang tetapi oleh negara dan sebesar - besarnya untuk kemakmuran rakyat.

Berdasarkan uraian di atas penulis menyimpulkan bahwa keadilan sosial dalam perpektif Sila Kelima Pancasila itu adalah keadilan politik dan keadilan ekonomi. Sama rata - sama rasa dalam lapangan politik dan lapangan ekonomi. Keadilan politik dan keadilan ekonomi yang dibangun di atas dasar kekeluargaan atau gotong royong atau semua untuk semua.

\section{Misi GKI Peterongan dalam Perspektif Sila Kelima Pancasila}

Misi berasal dari kata Latin 'missio' yang berarti perutusan. Kata mission adalah bentuk substantif dari kata kerja mittere (mitto, missi, missum) yang mempunyai beberapa pengertian dasar; (a) Membuang, menembak, membentur ; (b) mengutus, mengirim; (c) membiarkan, membiarkan pergi, melepaskan pergi; (d) mengambil/menyadap, membiarkan mengalir (darah). Kalangan gereja pada dasarnya menggunakan kata mittere dalam pengertian mengutus, mengirim. Di dalam Vulgatta kata 'mittere' adalah terjemahan dari kata Yunani 'Pempein' dan 'apostelein' yang juga berarti mengutus. Kedua istilah ini disebut 206 kali di dalam Kitab Suci Perjanjian Baru. Orang yang diutus atau misionaris diterjemahkan dari kata Yunani apostolos yang terdapat 79 kali dalam Kitab Suci Perjanjian Baru, sedangkan tugas yang mereka laksanakan disebut mission sebagai terjemahan dari kata Yunani apostole. Dalam penggunaan selanjutnya istilah mission dan apostole yang pada dasarnya mempunyai arti yang sama mendapatkan modifikasi pengertian seperti dalam istilah missionalis apostolus (kerasulan misioner) yang dipakai oleh Paus Pius XII dalam ensiklik misi Fidei Donum (1957). Kata apostole atau kerasulan dipakai untuk menunjuk kegiatan pastoral umum, sedangkan misi atau perutusan dipakai untuk kegiatan penyebaran iman ${ }^{25}$.

Hendrik Kraemer mengatakan bahwa misi berarti terpanggil untuk tugas perintisan baru. Sementara David J Bosch memaknai misi sebagai hal yang mengungkapkan hubungan yang

\footnotetext{
${ }^{24}$ (Latif, 2011:535)

${ }^{25}$ Edmund Woga, CScR. 2002. Dasar - Dasar Misiologi (Yogyakarta: Kanisius, 2002), 13-14
} 
dinamis antara Allah dan dunia. Bosch juga memaknai misi sebagai ciri keberadaan Kristen. Baginya misi adalah pernyataan diri Allah sebagai Dia yang mengasihi dunia, keterlibatanNya di dalam dan dengan dunia, sifat dan inisiatif-Nya yang merangkul gereja dan dunia. di mana gereja mendapatkan kesempatan istimewa untuk ikut serta di dalamnya. Misi terutama mengacu pada misi Allah (mission Dei) yang memberitakan kabar baik bahwa Allah adalah Allah untuk manusia. Misi juga berarti jawaban 'ya' Allah kepada dunia, misi merupakan partisipasi di dalam keberadaan Allah di dalam dunia. Misi mencakup penginjilan sebagai salah satu dimensi yang esensial yaitu pemberitaan keselamatan di dalam Kristus kepada mereka yang tidak percaya kepadanya, memanggil mereka untuk bertobat dan meninggalkan hidup yang lama, memberitakan pengampunan dosa serta mengundang mereka untuk menjadi anggota - anggota yang hidup dari komunitas Kristus di bumi untuk memulai kehidupan pelayanan kepada orang lain di dalam kuasa Roh Kudus ${ }^{26}$

Dalam perkembangannya misi mengalami polarisasi terutama dalam pemahaman dan pelaksanaannya oleh gereja - gereja, khususnya gereja - gereja ekumenikal dan evangelikal. Terhitung sejak tahun 1961 polarisasi antara ekumenikal dan evangelikal semakin terlihat dalam cara bermisi. Kaum evangelikal senantiasa membendung pengaruh liberalisme dalam lingkungan kehidupan gereja, khususnya metode penelitian Alkitab secara ilmiah yakni metode kritis historis. Kaum evangelikal selalu mempertahankan semangat misioner bagi evangelisasi dunia seperti yang terjadi pada abad - abad sebelumnya. Kaum evangelikal selalu menjawab dari sudut pandang mereka tentang masalah - masalah yang diakibatkan oleh modernisme, kebangkitan agama - agama non Kristen dan pluralitas kebudayaan. Gereja - gereja dari kalangan evangelikal agak berorientasi ke belakang. Mereka tidak seperti kalangan ekumenikal yang berani mengembangkan teologi, misi dan identitas yang dinamis seiring dengan kehidupan masyarakat dan lingkungan yang tidak pernah berhenti berkembang.

Sebenarnya usaha - usaha untuk mendefinisikan misi adalah sesuatu yang muncul belakangan. Gereja Kristen mula - mula tidak melakukan usaha seperti itu, sekurang kurangnya tidak secara sadar. Namun telaah terhadap teologi Matius, Lukas dan Paulus telah membuktikan bahwa tulisan - tulisan mereka dapat ditafsirkan sebagai usaha yang tidak putus - putusnya untuk mendefinisikan dan mendefinisikan ulang apa yang menjadi panggilan gereja untuk melakukannya dalam dunia pada zaman mereka. Sejak abad ke - 19 usaha mendefinisikan misi telah banyak sekali dilakukan.

\footnotetext{
${ }^{26}$ David J Bosch. Transformasi Misi Kristen (Jakarta:BPK Gunung Mulia, 1997), 13 - 16
} 
Semula misi dipahami sebagai usaha perluasan gereja secara triumfalistis dan para misionaris dilihat sebagai duta dari superioritas budaya bangsa - bangsa barat di atas budaya bangsa - bangsa di luar mereka. Karena gereja mengerti dirinya sebagai umat pilihan Tuhan, umat yang telah diselamatkan dalam Kristus dan yang harus menjadikan semua bangsa murid Kristus agar mereka diselamatkan. Ketika pengenalan gereja akan diri dan dunianya mengalami perubahan maka gereja tidak lagi menjadikan misinya sebagai propaganda iman tetapi misi dipandang sebagai komunikasi iman. Gereja dan sesamanya dipahami sama sebagai sesama ciptaan yang dikasihi dan diselamatkan Tuhan Sang Pencipta semua mahluk sebagaimana terungkap dalam konferensi gereja - gereja Protestan ekumenikal yang diselenggarakan sejak 1910 dan Konsili Vatikan II gereja Katolik yang perlangsung tahun $1962^{27}$.

Gereja - gereja Protestan ekumenikal dari masa ke masa mengalami perubahan perubahan dalam memahami misi sesuai dengang konteks zaman. Hal ini tampak dalam beberapa konferensi yang diselenggarakan. Pertama, dalam konferensi Edinburgh Skotlandia yang berlangsung pada tahun 1910 menyepakati bahwa lapangan misi tidak boleh lagi dibatasi hanya pada Asia dan Afrika saja, namun seluruh dunia. Misi bukan cuma tugas gereja - gereja Barat tetapi tugas semua gereja di seluruh dunia. Kedua konferensi Yerusalem yang berlangsung pada 1928 yang merupakan kelanjutan dari konferensi Edinburgh menyepakati bahwa pemahaman tentang misi tidak lagi sebagai usaha mengkristenkan dunia non barat, melainkan sebagai tugas bersama dalam menjawab masalah - masalah dunia ini, khususnya tantangan sekularisme, ateisme, komunisme dan masalah hubungan dengan agama Yahudi dan Islam. Dalam konferensi Yerusalem gereja - gereja Protestan dari kalangan ekumenikal melihat misi dalam wawasan keterbukaan agama Kristen terhadap perkembangan zaman. Ketiga dalam konferensi Tambaran di India Tahun 1938 dengan tema, 'World Mission of the Church' memaknai misi sebagai panggilan gereja di seluruh dunia dan menetapkan 'Amanat Agung' sebagai misi holistik berupa keselamatan pribadi dan perwujudan keadilan, kemerdekaan serta perdamaian ${ }^{28}$.

GKI Peterongan Semarang sebagai salah satu gereja yang memiliki pandangan -misi ekumenikal mendasarkan misinya pada konfesi GKI secara sinodal khususnya poin $8-10$. Konfesi itu berbunyi 'Anak Allah yang dikandung oleh Roh Kudus dan dilahirkan dari rahim perawan Maria, yang diutus untuk menegakkan kerajaan Allah bagi seluruh ciptaan, yang mengampuni orang berdosa serta memanggilnya bertobat, mengasihi semua orang tanpa

\footnotetext{
27 (Priana, 2017:141)

28 (Priana, 2017: 136-137)
} 
diskriminasi, menegakkan keadilan dan perdamaian tanpa kekerasan, memberkati setiap pribadi, keluarga dan anak - anak, memberdayakan orang miskin, memulihkan orang sakit, membebaskan orang tertindas, dan menjadi sahabat bagi orang yang diasingkan'. Konfesi itu didasarkan pada Injil Lukas 4:18,19, yang berbunyi, 'Roh Tuhan ada pada-Ku, oleh sebab Ia mengurapi Aku untuk menyampaikan kabar baik kepada orang - orang miskin, dan Ia telah mengutus Aku untuk memberitakan pembebasan kepada orang - orang tawanan, dan penglihatan bagi orang - orang buta, untuk membebaskan orang - orang tertindas, untuk memberitakan tahun rahmat Tuhan telah datang'.

Menurut Pendeta Jerdy Stevan salah seorang pendeta GKI Peterongan Semarang bahwa misi ini bermotif sosial dengan pendekatan secara holistik melalui ekonomi, pendidikan, bantuan sosial dan kesehatan. Menurutnya cara bermisi ini ditempu dengan kesadaran bahwa GKI Peterongan yang hidup dan besar di Indonesia memiliki panggilan untuk turut menyelesaikan persoalan - persoalan yang dialami oleh Indonesia. Persoalan - persoalan itu berupa kemiskinan, keterbelakangan, ketidakadilan, dll.

GKI Peterongan berpandangan bahwa Injil atau Kabar Baik itu adalah saat orang atau pribadi, persoalan atau pergumulan - pergumulannya diselesaikan. Saat mereka lapar mereka membutuhkan kabar baik bahwa ada yang hadir memberinya makan, saat mereka sakit mereka membutuhkan kabar baik bahwa ada yang mengobatinya, saat tertindas ada yang membebaskannya itulah kabar baik bagi mereka. Artinya bahwa cerita tentang Yesus yang inklusif dan berpihak pada orang - orang yang tertindas dan orang - orang lemah, mereka rasakan dalam perbuatan baik gereja kepada mereka, bukan sekadar mendengar kisah-Nya. GKI Peterongan mencoba melaksanakan misinya seperti yang diteladankan Yesus. Misi Yesus mencakup mereka yang miskin dan yang kaya, yang tertindas dan yang menindas, yang berdosa dan yang saleh. Misi-Nya adalah misi yang melenyapkan keterasingan dan menghancurkan tembok - tembok kebencian, misi yang melintasi batas - batas antara individu dan kelompok. Landasan misi GKI Peterongan ini selaras dengan semangat Sila Kelima Pancasila yang diperuntukkan untuk seluruh rakyat Indonesia tanpa membeda bedakan.

Hal ini senada dengan ungkapan Soepomo yang menyetujui pidato Soekarno dalam rapat BPUPKI. Soepomo mengatakan, 'Negara harus memperhatikan dan memenuhi semua kepentingan golongan dan individu sebagai warga negara secara ekual. Tidak boleh ada politik diskriminasi dalam bentuk dan alasan apa pun. Kelompok yang kuat atau mayoritas (ekonomi dan politik), tidak boleh karena mayoritas atau kuat, lalu memperoleh hak - hak dari negara melebihi kelompok lain, meskipun kecil dan lemah. UUD 1945 pasal 33 
menyebutkan bahwa semua kekayaan alam dan potensi Indonesia dikelola sedemikian rupa agar bermanfaat maksimal bagi segenap rakyat Indonesia. Tidak boleh ada penindasan ekonomi dalam Negara Kesatuan Republik Indonesia, yang kuat wajib menolong yang lemah sebagai satu keluarga yaitu keluarga Indonesia ${ }^{29}$.

Dengan misi demikian GKI Peterongan mencoba mewujudkan misinya dengan melakukan perbuatan - perbuatan Kristus. Seperti Kristus menyelam ke dalam masalah masalah yang dialami manusia demikianlah GKI Peterongan mencoba melaksanakan perutusannya. Karena itulah GKI Peterongan pada tahun 2015 - 2025 memiliki pernyataan visi berbunyi, 'Menjadi jemaat yang hidup di tengah perubahan zaman'. Dari pernyataan visi ini GKI Peterongan mengharapkan jemaatnya bertumbuh secara dinamis. Bertumbuh dalam kuantitas dan kualitas. Secara kuantitas diharapkan anggota jemaat semakin bertambah banyak yang ditandai dengan perluasan wilayah pelayanan, pertambahan pos - pos pelayanan, peningkatan fasilitas dan perkembangan bidang pelayanan serta terampil dalam memanfaatkan teknologi. Secara kualitatif diharapkan iman anggota jemaat bertumbuh secara progresif dalam kasih kepada Tuhan, kesatuan yang erat dengan sesama dan memahami Firman Tuhan dengan baik. Dengan pertumbuhan secara kualitas diharapkan pula tercipta kesatuan sesama orang percaya, menerima perbedaan satu dengan yang lain menuju kesempurnaan dan kedewasaan. Karena kedewasaan secara rohani akan menyebabkan tindakan, ucapan dan pemikiran yang berazaskan karakter Kristus. Dengan kualitas seperti ini setiap pribadi dalam jemaat akan mampu menangkal ajaran - ajaran yang keliru dan tangguh menghadapi perkembangan globalisasi ${ }^{30}$

Visi ini kemudian diterjemahkan ke dalam program - program yang disusun setiap dua tahun sekali. Program GKI Peterongan tahun 2017 - 2019 misalnya bertema, 'Gereja yang peduli bagi sesama dan dunia'. Dari semua program yang ada beberapa di antaranya memiliki narasi bertujuan untuk mewujudkan keadilan sosial sebagaimana tercatat dalam Rencana Kerja Anggaran (RKA) GKI Peterongan. Program - program tersebut dikelompokkan dalam beberapa kategori antara lain: 1). Program Kesaksian dan Pelayanan meliputi: Bantuan untuk Guru Agama Kristen, Perayaan Natal Sekolah Negeri, Bantuan untuk Yayasan - Yayasan Kristen, dan Pembelajaran Diakonia Transformastif. 2). Program Diakonia meliputi: Bantuan ke Dalam, Pengobatan dan Perawatan Orang Sakit/Meninggal Dunia serta Pemondokan dan Bantuan untuk Orang Jompo/Jemaat Tidak Mampu. 3) Program Pendidikan meliputi:

\footnotetext{
${ }^{29}$ (Latif, 2011: 536)

${ }^{30}$ GKI Peterongan. Rencana Kerja Anggaran GKI Peterongan 2017 - 2018. (Semarang: GKI Peterongan, 2017), 1
} 
Pemberian Beasiswa, Kebaktian Paskah dan Perayaan Natal Siswa Penerima Beasiswa. 4). Program Pelayanan Kasih meliputi: Bantuan insidentil, Bantuan Pelayan Firman dan Bantuan Sarana Prasarana Gereja - Gereja Kecil dan Bantuan Bencana Alam. 5). Program Kesehatan meliputi: Pelayanan Kesehatan Umum, Gigi dan Psikologi ${ }^{31}$.

Berdasarkan uraian dalam Buku RKA GKI Peterongan program - program tersebut mengacu pada acuan misi yang bernuansa sosial, ekonomi, pendidikan dan kesehatan. Pada umumnya program itu bermaksud untuk mewujudkan keadilan sosial, menyebarkan Injil Kristus kepada sesama, mencerdaskan kehidupan bangsa, meringankan beban sesama dan meningkatkan kesejahteraan jemaat dan masyarakat sekitar lingkungan gereja ${ }^{32}$. Meski sasarannya adalah jemaat dan masyarakat luas namun berdasarkan observasi penulis realisasi program - program tersebut sebagian besar hanya menyasar orang - orang Kristen saja seperti anggota GKI Peterongan, anggota gereja - gereja di luar GKI Peterongan dan yayasan yayasan sosial Kristen.

Program - program GKI Peterongan yang realisasinya hanya menyasar orang - orang Kristen saja menunjukkan bahwa GKI Peterongan masih terjebak dalam sikap eksklusivisme. GKI Peterongan masih membeda - bedakan berdasarkan agama. Sikap GKI Peterongan itu, menurut salah seorang narasumber karena orang - orang Kristen masih banyak yang membutuhkan bantuan sehingga harus menjadi prioritas sebelum keluar membantu yang lain. 'Kita harus lebih dahulu memperhatikan saudara - saudara seiman' katanya. Sikap ini belum sesuai dengan cita - cita sila kelima Pancasila yang mengharapkan keadilan bagi seluruh rakyat Indonesia. Keadilan berdasarkan Sila Kelima adalah keadilan yang tidak membeda bedakan agama, suku dan ras. Sikap GKI Peterongan ini eksklusif dan belum selaras dengan prinsip keadilan sosial berdasarkan sila kelima Pancasila yang ditujukan untuk seluruh rakyat Indonesia tanpa diskriminasi.

John Titaley, Guru Besar Ilmu Teologi mengungkapkan bahwa eksklusivismelah yang mengakibatkan adanya sikap membeda - bedakan berdasarkan agama. Titaley juga mengatakan bahwa sikap eksklusif bisa menjadi salah satu akar yang dapat menimbulkan berbagai sikap yang tidak toleran sehingga perdamaian antar agama - agama akan sulit tercapai . Kekristenan sendiri mewarisi sikap ekslusif itu sebagai salah satu di antara agama -

\footnotetext{
${ }^{31}$ (GKI Peterongan, 2017:45)

32 (GKI Peterongan, 2017:45-61)
} 
agama Abrahamik yang berakar pada pandangan yang mengatakan di luar Gereja tidak ada keselamatan (extra ecclesia nulla salus) ${ }^{33}$.

Mengenai hal tersebut Titaley mengusulkan agar pemahaman eksklusivisme itu tidak diterapkan dalam kehidupan berbangsa dan bernegara di Bumi Pancasila, Indonesia. Menurutnya pemahaman tentang Yang Maha Kuasa yang dikenal Bangsa Yahudi dalam budayanya sebagai Yahweh dan Bangsa Indonesia mengenalnya dengan Tuhan Yang Maha Esa harus disadari sudah bekerja dalam sejarah Indonesia yang beragama Islam, Kristen, Hindu, Budha, dll. Semua agama tersebut mengalami berkat dan rahmat yang sama dari Tuhan Yang Maha Esa sehingga bisa mendapatkan kemerdekaannya 17 Agustus $1945^{34}$.

Karena itu agama - agama tersebut harus saling mendukung dan menolong. Seperti ungkapan Pdt. Andreas Yewangoe bahwa, 'Tugas Kristen bukan menobatkan agama - agama lain, tetapi agama Kristen diamanatkan untuk memurnikan dan merealisasikan maksud maksud agama mereka... Tugas Kristen adalah membuat orang - orang menjadi penganut Budha, (Islam, Hindu, konghucu, dll) yang lebih baik' ${ }^{35}$.

Jika melihat dari pelaksanaan dan tujuan misi GKI Peterongan tersebut dalam program program, maka GKI Peterongan baru berorientasi pada misi perluasan iman (kristenisasi). Hal ini terlihat dari motif program - programnya yang masih berorientasi pada perluasan wilayah pelayanan melalui pembukaan pos - pos pelayanan dan penambahan jiwa - jiwa baru.

Dari perspektif sila kelima Pancasila tujuan dan pelaksanaan misi GKI Peterongan Semarang belum mengarah pada terwujudnya keadilan politik dan keadilan ekonomi. Hal ini terlihat dalam program - program GKI Peterongan, belum ada usaha perjuangan untuk mewujudkan, sama rata - sama rasa menurut konstitusi NKRI. Demikian pula di bidang ekonomi belum ada usaha untuk mewujudkan sama rata - sama rasa dalam lapangan ekonomi. Artinya misi dan program - program GKI Peterongan meski semangatnya senada dengan cita - cita sila kelima Pancasila untuk mewujudkan keadilan sosial, namun pelaksanaannya dalam program - program belum menunjukkan prinsip keadilan dalam perspektif Sila Kelima Pancasila yaitu keadilan politik dan keadilan ekonomi.

Kenyataan lain, bahwa misi GKI Peterongan yang diimplementasikan dalam program program masih bersifat eksklusif belum berorientasi untuk semua orang. Di samping itu program - program yang ada belum berorientasi pada perwujudan keadilan sosial karena

\footnotetext{
${ }^{33}$ Prof John A. Titaley. Menelusuri Akar - Akar Eksklusivisme Agama Abrahamik, Volume 4 (Semarang: e-Journal Elsa, Januari 2018), 2

34 (Titaley, 2018:2) 658

${ }^{35}$ Ebenhaeze I Nuban Timo, Menghariinikan Injil Di Bumi Pancasila (Jakarta: BPK Gunung Mulia, 2017),
} 
sifatnya masih karitatif (sementara) belum transformatif. Menurut pandangan penulis bahwa bantuan yang hanya bersifat karitatif tidak akan banyak membantu masyarakat untuk mewujudkan kesejahteraannya secara ekonomi justru sebaliknya bisa menimbulkan sifat malas dan tidak mau bekerja keras bagi mereka yang menerima bantuan, sehingga mereka akan tetap miskin.

Melihat hal ini menjadi relevan apa yang dikatakan Prof. Dr. H. Soedijarto, M.A bahwa salah satu penyebab belum terwujudnya keadilan sosial bagi seluruh rakyat Indonesia itu karena belum dipahami dan diupayakannya secara sungguh - sungguh Pancasila sebagai landasan filosofi dan ideologi dari Negara Republik Indonesia ${ }^{36}$. Belum berjalannya misi GKI Peterongan dalam perspektif keadilan sosial karena GKI belum memikirkannya secara serius. Hal ini senada dengan ungkapan salah seorang pendeta GKI Peterongan yang mengatakan bahwa, 'GKI Peterongan belum secara serius memikirkan hal ini disamping karena belum adanya pendeta khusus yang paham tentang gerakan sosial, anggaran gereja juga delapan puluh persen habis untuk operasional internal gereja'. Hal ini dikuatkan dengan pelaksanaan program - program yang belum berorientasi pada perwujudan keadilan sosial sebagaimana cita - cita konstitusi Indonesia - keadilan sosial bagi seluruh rakyat Indonesia.

\section{Kesimpulan}

Keadilan sosial bagi seluruh rakyat Indonesia adalah cita - cita Indonesia merdeka. Demi mewujudkan cita - cita tersebut maka Negara Kesatuan Republik Indonesia menjadikan keadilan sosial sebagai salah satu unsur yang menyusun ideologi negara dalam Pancasila sebagaimana termaktub dalam sila kelima yang berbunyi, 'Keadilan sosial bagi seluruh rakyat Indonesia'. Selanjutnya hal tersebut diatur secara khusus melalui konstitusi negara dalam UUD 1945 khususnya Pasal 27 - 33.

GKI Peterongan sebagai bagian integral dari bangsa Indonesia memiliki mimpi yang sama untuk mewujudkan cita - cita Indonesia merdeka tersebut. Karena itulah GKI Peterongan mendasarkan misinya pada konfesi GKI yang berbunyi, “Anak Allah yang dikandung oleh Roh Kudus dan dilahirkan dari rahim perawan Maria, diutus untuk menegakkan kerajaan Allah bagi seluruh ciptaan, yang mengampuni orang berdosa serta memanggilnya bertobat, mengasihi semua orang tanpa diskriminasi, menegakkan keadilan dan perdamaian tanpa kekerasan, memberkati setiap pribadi, keluarga dan anak - anak, memberdayakan orang miskin, memulihkan orang sakit, membebaskan orang tertindas, dan menjadi sahabat bagi orang yang diasingkan. Dikuatkan pula dengan Lukas 4: 18,19, yang

\footnotetext{
${ }^{36}$ Agus Wahyud. Proceeding Pancasila (Yogyakarta: Mahkamah Konstitusi, 2009), 387
} 
berbunyi 'Roh Tuhan ada pada-Ku, oleh sebab Ia mengurapi Aku untuk menyampaikan kabar baik kepada orang - orang miskin, dan Ia telah mengutus Aku untuk memberitakan pembebasan kepada orang - orang tawanan, dan penglihatan bagi orang - orang buta, untuk membebaskan orang - orang tertindas, untuk memberitakan tahun rahmat Tuhan telah datang'.

Meski Misi GKI Peterongan memiliki semangat yang sama dengan Sila Kelima Pancasila, namun ada kesenjangan dalam aktualisasinya melalui program - program. Program - program GKI Peterongan yang bernafaskan keadilan sosial belum sepenuhnya mengaktualisasikan nilai keadilan sosial berdasarkan Pancasila. Terlihat bahwa GKI Peterongan Semarang belum bersungguh - sungguh dan serius untuk mewujudkan cita - cita Indonesia merdeka tersebut. Tampak jelas bahwa program - program GKI Peterongan baru sebatas bantuan sosial yang bersifat karitatif (jangka pendek) dan belum mengarah pada pemberdayaan ekonomi transformatif (jangka panjang) yang bisa membuat masyarakat berdaya secara ekonomi untuk mewujudkan masyarakat adil dan makmur. Selain itu tidak ada usaha - usaha yang dilakuakn GKI Peterongan untuk memperjuankan jemaatnya atau pun rakyat luas agak memperoleh hak - haknya secara konstitusioal berdasarkan Pancasila dan UUD 1945. Artinya Kabar Baik bagi orang - orang miskin, pembebasan bagi orang - orang tawanan dan yang tertindas serta penglihatan bagi orang - orang buta, dll belum tersampaikan dengan baik dalam tindakan. Program - Program GKI Peterongan masih sebatas solidaritas sosial belum mencerminkan kepedulian sosial yang total kepada sesama.

Sebagai gereja yang memiliki semangat misi selaras Sila Kelima Pancasilah, GKI Peterongan sebagai bagian intergral dari Indonesia seharusnya melepaskan diri dari Eksklusivisme sebagaimana Indonesia yang diproklamirkan 17 Agustus 1945 keluar dari eksklusivisme agama dan suku - suku menjadi satu bangsa sederajat dalam keberagaman dengan tidak membeda - bedakan berdasarkan Pancasila dan UUD 1945. Jika perlu GKI Peterongan menjadi role model sebagai gereja yang menghidupkan nilai - nilai Pancasila terkhusus keadilan sosial dalam realitas kesehariaannya dan mengajak anak bangsa lainnya mengawal penegakkan nilai - nilai yang terkandung di dalamanya. Hal ini bisa dilakukan jika GKI Peterongan tak lagi bercorak single - center (berpusat pada gereja (warganya) saja) tetapi arus bercorak multisentra (untuk semua orang).

Don Richardson Misiolog dan Ednograf di Suku Sawi Papua mengatakan, 'Yesus dan para murid tidak hanya bertemu dan menolong orang - orang di Sinagoge'. Lebih lanjut Richardson menjelaskan bahwa, 'Penganiayaan murid - murid di Yerusalem dan perjumpaan Saulus dengan Yesus, dan penetapannya sebagai rasul bangsa - bangsa lain serta penghacuran 
Yerusalem pada Tahun 70 oleh Jenderal Titus merupakan cara Tuhan menolak pengkultusan Yerusalem, ${ }^{37}$. Karena itulah gereja harus membangun pemahaman multisentra sehingga keadilan sosial bagi semua orang bisa terwujud.

Akhirnya menarik untuk mengingat sebuah ungkapan yang mengatakan, 'Jadi tanpa kerja keras, mimpi tidaklah ada artinya. Ibarat Anda bermimpi pada malam hari makan makanan lezat tetapi anda bangun di pagi hari dengan perut yang tetap keroncongan ${ }^{38}$. Mimpi akan terwujudnya keadilan sosial bagi semua harus diikuti dengan perencanaan serius dan kerja keras yang tak tanggung - tanggung.

\section{Referensi}

${ }^{1}$ https://www.bps.go.id. Data ini dirilis Badan Pusat Statistik RI tanggal 2 Januari 2018.

Diakses 17 Agustus 2018

${ }^{2}$ https/jateng.bps,id/pressrilis2januri2018. Diakses 17 Agustus 2018

${ }^{3}$ Sinode GKI, https://www.gki.or.id/ diakses 17 Agustus 2018

${ }^{4}$ Wawancara dengan Pendeta GKI Peterongan Jerdi Stevan, Semarang 16 Agustus 2018

${ }^{5}$ Wawancara dengan narasumber 16 Agustus 2018

${ }^{6}$ Wawancara dengan narasumber 14 Agustus 2018

${ }^{7}$ Wawancara dengan narasumber 16 Agustus 2018

Aning, Floriberta, Lahirnya Pancasila (Yogyakarta: Media Pressindo, 2016)

Bosch, David J, Transformasi Misi Kristen (Jakarta: Gunung Mulia, 1997)

Creswel, John W, Reseach Desaign (Yogyakarta: Pustaka Pelajar, 2010)

GKI Peterongan, Rencana Anggaran GKI Peterongan 2017-2018 (Semarang: GKI Peterongan, 2017)

Haryprabowo, Y, 'Misi Gereja Di Tengah Pluralitas Agama Dan Budaya', Orientasi Baru, Vol.18 (2009), 33-49<http://ejournal.usd.ac.id/index.php/job/article/download/1395/1136>

Jebadu, Alexander, 'Dimensi Politik Dari Misi Pembebasan Gereja Bagi Orang Miskin Dan Pemeliharaan Alam Ciptaan', Teologi, Vol. 6 (2017), 167-86 <http://ejournal.usd.ac.id/index.php/jt/article/view/1001>

Latif, Yudi, 'Negara Paripurna Historisitas, Rasionalitas Dan Aktualitas Pancasila.' (Jakarta: PT Gramedia Pustaka Utama, 2011), p. 494

Manullang, Sudianto, 'Konsep Misi Diakonia Untuk Konteks Indonesia', Stulos, Vol.16 (2018), 28-46 <http://www.sttb.ac.id/download/stulos/stulos-v16-no01/Stulos-V16-no012-KONSEP MISI-DIAKONIA UNTUK KONTEKS INDONESIA.pdf>

Messak, Tobias, Konsep Keadilan Pancasila (Salatiga: Satya Press, 2007)

Nuban Timo, Ebenhaeze I, Menghariinikan Injil Di Bumi Pancasila (Jakarta: BPK Gunung Mulia, 2017)

Nugroho, Fibry Jati, 'Gereja Dan Kemiskinan: Diskursus Peran Gereja Di Tengah Kemiskinan', Evangelikal, Vol. 3 (2019), 100-112

<https://journal.sttsimpson.ac.id/index.php/EJTI/article/view/128>

\footnotetext{
${ }^{37}$ (Nuban Timo, 2017:658)

${ }^{38}$ Piter Randan Bua, Berkaca Pada Kepemimpinan Ahok (Yogyakarta: Taman Pustaka Kristen, 2013),
} 
Pamoe, Raharjo, Bung Karno Dan Pancasila (Yogyakarta: Galang Press, 2002)

Priana, Made I, Misi Gereja Protestan Bali (Salatiga: Fakultas Teologi UKSW, 2017)

__, 'Rekontruksi Misi Gereja Di Indonesia Dari Perspektif Pancasila Sebagai Religiositas Sipil Indonesia', Waskita, Vol. 3.Sosiologi Agama (2016) <http://ejournal.uksw.edu/waskita/article/view/1307/647>

Randan Bua, Piter, Berkaca Pada Kepemimpinan Ahok (Yogyakarta: Taman Pustaka Kristen, 2013)

Siagian, Fredy, 'Rekontruksi Misi Gereja Di Abad 21', Sintax Literate, Vol. 1 (2016), 1-13 <http://www.jurnal.syntaxliterate.co.id/index.php/syntax-literate/article/view/31>

Soekarno, Revolusi Indonesia (Yogyakarta: Galang Press, 2002)

Stevanus, Kalis, 'Mengimplementasikan Pelayanan Yesus Dalam Konteks Misi Masa Kini Menurut Injil Sinoptik', Fidei, Vol. 1 (2018), 284-95 <http://www.stttawangmangu.ac.id/e-journal/index.php/fidei/article/view/21>

Tarpin, 'Misi Kristen Di Indonesia Bahaya Dan Pengaruhnya Terhadap Umat Islam', Ushuluddin, Vol.17 (2011), 38-53 <http://ejournal.uinsuska.ac.id/index.php/ushuludin/article/view/681>

Titaley, John A, 'Menelusuri Akar - Akar Eksklusivisme Agama - Agama Abrahamik', Vol. 4.Sosiologi Agama (2018), 2

Wahyudi, Agus, Proceeding Pancasila (Yogyakarta: Mahkamah Konstitusi, 2009)

Woga, Edmund, Dasar - Dasar Misiologi (Yogyakarta: Kanisius, 2002) 